\title{
First report of Fusarium redolens causing Fusarium yellows on chickpea in Algeria
}

\author{
Souad Zaim ${ }^{1}$ (D) Ahmed Amine Bekkar ${ }^{1}$
}

Received: 30 October 2021 / Accepted: 7 January 2022 / Published online: 18 January 2022

(c) The Author(s) under exclusive licence to Società Italiana di Patologia Vegetale (S.I.Pa.V.) 2022

Keywords Cicer arietinum $\cdot$ Wilt-like disease $\cdot$ Fusarium redolens $\cdot$ Pathogenicity

In June 2019, twelve chickpea (Cicer arietinum) fields in the region of Mascara, Northwestern Algeria, showed plants with leaf yellowing or necrosis that started from the bottom shoots and gradually went up (disease incidence of about $75 \%$ ). Seventy stem tissues from 24 symptomatic plants were surface disinfected and cultured on potato dextrose agar (PDA) at $25{ }^{\circ} \mathrm{C}$. Twenty fungal isolates showed aerial mycelial morphotype on PDA with white to pink pigmentations. Abundant microconidia, mostly single-celled $(6.5-9.1 \times 3.3-4.3 \mu \mathrm{m})$, and uncommon septate macroconidia $(29.2-37.3 \times 3.8-4.2 \mu \mathrm{m})$ were observed. Chlamydospores were mostly globose $(8.1 \mu \mathrm{m}$ mean diameter). The cultural and morphological characteristics were similar to Fusarium redolens Wollenw (Leslie and Summerell 2006). The internal transcribed spacer (ITS) and translation elongation factor 1-alpha (TEF-1 $\alpha$ ) of the representative isolate (FRC) were amplified, sequenced and deposited in GenBank (accession Nos. ITS: MW519908; TEF1- $\alpha$ : MZ151166) (White et al. 1990; Carbone and Kohn 1999). BLASTn analysis of the obtained sequences showed $99.82 \%$ and $100 \%$ identities to reference sequences MT446126 (ITS) and MK937112 (TEF1-a) of $F$. redolens, respectively. Phylogenetic analysis of concatenated sequences clustered FRC readily and consistently with reference $F$. redolens strains. The pathogenicity test of FRC was carried on 8-day-old seedlings lines ILC482 of chickpea by $1 \mathrm{~cm}$ submersion of trimmed roots in a spore suspension $\left(10^{6}\right.$ microconidia $\left./ \mathrm{ml}\right)$. Control plants were immersed in sterile distilled water. All plants were maintained in a greenhouse for 40 days at $25^{\circ} \mathrm{C}$. Up to $100 \%$ disease incidence occurred on inoculated plants

Souad Zaim

zaimsouad1528@yahoo.fr; s.zaim@univ-mascara.dz

1 Laboratory of Research On Biological Systems and Geomatics (L.R.S.B.G), Department of Agronomy, Faculty of Life and Natural Sciences, University of Mustapha Stambouli Mascara, Mascara, Algeria after 24 days. The symptoms were similar to those observed in the field. No symptoms were observed on the control seedlings. The fungus was re-isolated and identified as $F$. redolens, fulfilling Koch's postulates. To our knowledge, this is the first report of Fusarium redolens as the causal agent of Fusarium yellows on chickpea in Algeria.

Supplementary information The online version contains supplementary material available at https://doi.org/10.1007/s42161-022-01044-y.

Data availability Data are available on request from the authors.

\section{Declarations}

Informed consent This manuscript describes original work and is not under consideration elsewhere. All authors approved the manuscript and this submission.

Conflicts of interest The authors declare no conflict of interest.

Research involving human participants and/or animals Did not involve research with animals and humans.

\section{References}

Carbone I, Kohn LM (1999) A method for designing primer sets for speciation studies in filamentous ascomycetes. Mycologia 91(3):553-556.https://doi.org/10.1080/00275514.1999.12061051

Leslie JF, Summerell BA (2006) The Fusarium Laboratory Manual. Blackwell Publishing: Hoboken, 238-240. https://doi.org/10. 1002/9780470278376

White TJ, Bruns T, Lee S, Taylor J (1990) Amplification and direct sequencing of fungal ribosomal RNA genes for phylogenetics. In: Innis MA, Gelfand DH, Sninsky JJ, White TJ (ed) PCR Protocols: A Guide to Methods and Applications. San Diego, CA, USA: Academic Press, 315-322. https://doi.org/10.1016/B978-0-12-372180-8.50042-1

Publisher's Note Springer Nature remains neutral with regard to jurisdictional claims in published maps and institutional affiliations. 